\title{
EFFECT OF 10 WEEKS GAME EXPERIENCE LEARNING (GEL) BASED TRAINING ON TEAMWORK, RESPECT ATTITUDE, SKILL AND PHYSICAL ABILITY IN YOUNG FOOTBALL PLAYERS
}

\author{
Sulistiyono ${ }^{1 \mathrm{ABCDE}}$, Andry Akhiruyanto ${ }^{2 \mathrm{CD}}$, Nawan Primasoni ${ }^{3 \mathrm{AD}}$, Fatkurahman Arjuna ${ }^{3 \mathrm{AD}}$, \\ Nurhadi Santoso $^{3 \mathrm{AD}}$, Dewangga Yudhistira ${ }^{\mathrm{BCD}}$
}

${ }^{1}$ Yogyakarta State University

${ }^{2}$ Universitas Negeri Semarang

${ }^{3}$ Sebelas Maret University

Authors' Contribution: A - Study design; B - Data collection; C - Statistical analysis; D - Manuscript Preparation; E - Funds Collection

Corresponding Author: Sulistiyono, E-mail: sulistiyono@uny.ac.id

Accepted for Publication: June 14, 2021

Published: June 25, 2021

\section{DOI: 10.17309/tmfv.2021.2.11}

\begin{abstract}
This study aims to examine the effectiveness of the games experience learning-based training against teamwork, respect attitude, skills, and physical ability of young footballers.

Materials and methods. Participants consisted of young male football players who had participated in matches at the district, provincial and national levels. The number of participants involved amounted to 46 divided into control and intervention groups of 23 parties each. Footballers aged 10-12 years old have a height of $140.98 \pm 7.23 \mathrm{~cm}$, an average body weight of $34.33 \pm 8.64 \mathrm{~kg}$. Instruments in this study consist of instruments to measure teamwork and respect attitude in the form of expert validated observation rubrics, passing, and dribbling skill tests, 30-meter sprints, vertical jumps, and multistage fitness tests to measure physical ability of speed, leg power, and aerobic endurance.

Results. Descriptive data showed mean values and standard deviations of control and intervention groups there were differences, the intervention group had a mean value and better deviation standards, while the hypothesis test using the Mann-Whitney test obtained a teamwork attitude score of $0.039<0.05$; respect attitude of $0.009<0.05$; passing skills of $0.039<0.05$; dribbling skills of $0.000<0.05$; speed ability of $0.004<0.05$; leg power of $0.002<0.05$; Endurance of $0.020<0.05$. That from the significance value of the control and intervention group $(\mathrm{p}<0.05)$ it can be concluded that the variables of teamwork, respect attitude, passing, dribbling, speed, power, and endurance on the posttest value are not the same and the average value of all variables descriptively the intervention group has a higher average value. Conclusions. There is a significant influence statistical analysis on teamwork, respect attitude, skill techniques, and physical ability for young football players thus training with the game experience learning model can be one solution to improve the performance of youth football.
\end{abstract}

Keywords: training, games experience learning, youth football player.

\section{Introduction}

Training aims to improve skills and competence (Schroepf \& Lames, 2017; Balyi \& Way, 2014; Khudolii et al., 2019). Besides, it enhance personal development and a high degree of health (Kavussanu \& Spray, 2006; Harwood, 2008; Gilbert et al., 2001; Henry, 2013). Training is not only meant to improve physical aspects but also has specific objectives which include, providing positive personal development, character, and social life interactions skills for young athlete.

(c) Sulistiyono, Akhiruyanto, A., Primasoni, N., Arjuna, F., Santoso, N., Yudhistira, D., 2021.
Moreover, in football, young athletes are technically trained with regards to the feeling and level of individual intelligence (Hyballa \& te Poel, 2015).

The pattern of movement in football is carried out with low, moderate, and maximal intensity. Professional footballers can run 9-13 kilometers during a game, but the frequent mileage is with low intensity and most importantly a period of running with maximal intensity (Bangsbo, 2014). Motion analysis with modern technology has shown that professional footballers run at $28 \%$ more high intensity (2.43 vs 1.90 kilometers) and 58\% more sprints with distances (650 vs 410 meters) than amateur footballers (Bangsbo, 2014; Mohr et al., 2003). 
This ability is a determining factor for maximum achievement. Furthermore, it was also stated that the ball receiving ability is at a running scores of $64 \%$ (Rampinini et al., 2007), hence, ball possession training during high-intensity sessions have a positive impact on footballers performance. Also, technical training using low to high-intensity sessions have a positive impact on players' selfconfidence. The training intensity is modified based on the size of the field, numbers of player, motivation from the coach, and special rules (Bangsbo, 2008). Furthermore, modern football needs to be designed with specific training methods which suits players' needs including technical, tactical, and physical aspects. For example, center-backs cover less total distance and run with moderate intensity compared to other positions Conversely, midfielders are expected to demonstrate high-intensity performance and short recovery (Mohr et al., 2003; Bradley et al., 2009). Therefore, variations in frequency and training intensity are important in maximizing athlete performances. In this sport, the aspects studied are very complex and not only improves individual quality but also enhance teamwork.

Sports activities are regarded as positive activities because it involves participation, competition, communication, it is also believed to develop an attitude of respect and cooperation (Goncalves et al., 2010; Khudolii et al., 2020). Teamwork is an absolute requirement to win matches because football is a sport of collectivity. A team consists of two or many individuals that contributes to one another to achieve a common goal, which is to win a match (Malone \& Lorimer, 2020). Furthermore, teamwork refers to an interactive and interdependent behavior among a team (McEwan et al., 2017). For example, a midfielder passes the ball to a teammate with more developed football strategy hence, there is tendency of scoring goals against the opponents (McEwan et al., 2017). The effectiveness of teamwork is believed to be a factor in the realization of a goal (Feigean et al., 2018). It is also reported that footballers need to work together, innovative and develop scientifically to be more advanced and to compete with other teams (Wang, 2020). One of the most important points in football is the technical aspect (Wang, 2020).

Performance sports, especially football, is inseparable from good technique. This is an important requirement to win the ball, strategize in outwitting opponents, receiving and passing the ball as well as scoring goals (Rello \& Widiyanto, 2019). Therefore, basic techniques needs to be studied and mastered perfectly as this determines whether a team wins or loses (Doewes et al., 2020). Furthermore, dribbling and passing are important basic components because when a player arranges an attack, the defender is expected to pass the ball according to the goal, hence, the attacker needs to pass the opponent with perfect dribbling (Doewes et al., 2020). A side good basic techniques, the physical features also plays an important role in winning.

Football is about scoring in the opponent's goal in order to win matches (Romeas et al., 2016). In the attack and defense line, the physical aspect is very much required, without it, football players fail to display maximum performance. Moreover, physicality is one of the most important aspects of performance sports hence, when an athlete has a good physique, such individual automatically becomes more effective and efficient in both defensive and attacking duties (Dewangga, 2020). Meanwhile, Wang (2020) stated that football as a collective sport often involves confrontation which leads to physical contact hence, when physical aspects are not programmed from an early age as a foundation, young players often experience injuries. This is line with McKinney's et al. (2019) which stated that an athlete is an individual, with excellent physical condition to win in certain sports. Physical aspects are properly programmed when peak performance is achieved. The integral components in football include speed, endurance, and power. These three aspects greatly influence the success of an individual and a team physically. However, to develop these aspects, especially in soccer, it is necessary to carry out special trainings capable of improving athletes' development.

The major problem for adolescent, especially in football is performance development. Previous studies have applied special training methods to improve physical and tactical aspects. As with the small-sided game method, this technique is popular among footballers from amateurs to professionals. Besides, this method is considered suitable because it improves physical abilities, technical skills, and tactics (Fradua et al., 2013; Hill-Haas et al., 2011; Reilly, 2005). However, based on observations, the small-sided game method lacks focus in the aspect of skills, for example, young players without basic techniques knowledge, have difficulties with passing and dribbling, hence, its application is more suitable for athletes with good technique. Furthermore, Ben Khalifa et al. (2021) in a study titled effects of verbal interactions on skills among students, examined the effectiveness of students' verbal interaction on skill, performance, and game development in football learning. However, the study focused more on physical education and rather than cognitive development. In addition, most previous studies only examined two dependent variables, which are technique and physical ability, only few studies applied three or more dependent variables. Therefore, to deal with the gaps and lack of research, this study applies a game experience learning-based training method developed by the author and aimed at improving teamwork, respect attitude, skills, and physical abilities in young soccer players.

\section{Materials and methods}

\section{Study participants}

This study was conducted using an experimental method with two groups, namely control and intervention. The participants were 46 male football players aged 10-12 years with an average height and body weight of $140.98 \pm 7.23 \mathrm{~cm}$ and $34.33 \pm 8.64 \mathrm{~kg}$ respectively. In addition, participants were given a preliminary test before treatment. Afterwards, the pretest results were ranked from the highest to the lowest order. The players were divided into two groups using match subject ordinal pairing pattern, therefore, both groups were balanced in various aspects. Moreover, group A, regarded as control used the conventional training model while group $\mathrm{B}$ applied the games experience training method.

This training model resulted from a developmental study, validated by experts using the Aiken technique with a score of 4.46 (very good). Participants were trained by two head coaches and two assistants with 23 young football athletes in each group. The respondents received treatment in form of training with a frequency of 3 times per week for 10 weeks and were selected to participate in district, provincial, and national football competitions. The training was carried out for 90 minutes for each session. 
Sulistiyono, Akhiruyanto, A., Primasoni, N., Arjuna, F., Santoso, N., \& Yudhistira, D. (2021). Effect of 10 Weeks Game Experience Learning (Gel) Based Training on Teamwork, Respect Attitude, Skill and Physical Ability in Young Football Players

Table 1. Games experience learning-based training procedure

\begin{tabular}{cll}
\hline \multicolumn{1}{c}{ Training Stages } & \multicolumn{1}{c}{ Training Material } & \multicolumn{1}{c}{ Strategy } \\
\hline Warming up & \multicolumn{1}{c}{ Warm-up activity } & \multicolumn{1}{c}{ Guided activity } \\
\hline Core Training 1 & $\begin{array}{l}\text { Games to develop character values (compiled by the } \\
\text { author) }\end{array}$ & $\begin{array}{l}\text { Experience-based learning activities (playing, reflecting, } \\
\text { discovering, and implementing) }\end{array}$ \\
Core Training 2 & $\begin{array}{l}\text { Games to develop specific technical skills (analyzed, } \\
\text { selected, and designed by the author) } \\
\text { Experiential learning activities (playing, reflecting on, } \\
\text { discovering, and applying) }\end{array}$ \\
Core Training 3 & $\begin{array}{l}7 \text { on 7 football matches based on the federation rules of } \\
\text { play }\end{array}$ & $\begin{array}{l}\text { Play is guided by at least one transfer of game rules } \\
\text { Cooling Down activity }\end{array}$ \\
\hline
\end{tabular}

\section{Study organization}

The participants reported for treatments 3 times per week while the minimum player attendance was $80 \%$ in 10 weeks. Teamwork and respect attitude were measured using expert validated rubric observational, meanwhile, special instruments were used for passing and dribbling tests, and the 30-meter sprint, vertical jump, and multistage fitness tests were used to measure the physical ability including speed, power, and endurance. The procedure for the game experience learning-based training is presented table 1.

The experimental group was given 10 weeks a training intervention with the content of the exercise consisting of games for the development of respect and teamwork behavior in the 1 st core exercise, games for the development of technical skills in the 2 nd core exercise, and the 3rd core exercise as a time to apply the results of the reflection phase by doing 7vs7 football activities with standard rules of play. The games used to treat the experimental groups can be read in table 2, while the control groups are given the treatment of conventional exercise models.

Table 2. Games based on experience learning for the 1st and 2nd core exercises

\begin{tabular}{|c|c|c|}
\hline No & $\begin{array}{c}\text { Game for } 1 \text { st core } \\
\text { training }\end{array}$ & Game for 2 nd core training \\
\hline 1 & Fishing Ball & 3 vs 1 \\
\hline 2 & $\begin{array}{l}\text { Passing Down Through } \\
\text { the Fortress }\end{array}$ & 4 vs 2 \\
\hline 3 & Together we can & 3 vs 2 , and Finishing \\
\hline 4 & Time Bomb & 3 Vs $3+2$ Neutral Player \\
\hline 5 & Pair Two Two & 4 vs $4+4$ Neutral Player \\
\hline 6 & Team Frog Jump & 4 vs 2 Becomes 6 vs 4 \\
\hline 7 & Goal, Goal, Goal & 3 vs $3+4$ Neutral Player \\
\hline 8 & Red Card & 4 vs $2+1$ Player \\
\hline 9 & Horse Soccer & 3 vs 3, (Goa Break) \\
\hline 10 & Precious Feet & Passing Obstacles or 3 vs $1(+2)$ \\
\hline 11 & Fair Play Games & Ball Control Create Shooting Space \\
\hline 12 & Shooting Prisoner & $\begin{array}{l}\text { Placing Bombs in Villains' Nests } \\
\text { (1 vs } 1 \text { ) }\end{array}$ \\
\hline 13 & Happy and Sad & $\begin{array}{l}\text { Break through the Opponent's } \\
\text { Defense Area }\end{array}$ \\
\hline 14 & $\begin{array}{l}\text { Go Back So Door Drible } \\
\text { Ball }\end{array}$ & $\begin{array}{l}\text { Splitting the Opponent's Fortress } \\
\text { (5 vs } 5 \text { ) }\end{array}$ \\
\hline 15 & Holding 1 on 1 & Dribbling 3 vs 2 \\
\hline 16 & Chain Ball & Create Space for Shooting \\
\hline 17 & Police Vs Prisoner & 4 vs 4 In Restricted Area \\
\hline 18 & Treasure Guard & $\begin{array}{l}3 \mathrm{vs} 3 \text {, in the box, } 3 \mathrm{vs} 3 \text { out of the } \\
\text { box }\end{array}$ \\
\hline
\end{tabular}

\section{Statistical analysis}

Data processing was conducted using SPSS 25. The first step involve comparing descriptive data with the size of the entire population and the distribution of variables thereafter, the mean and standard deviation (SD) were determined. Furthermore, the Mann Whitney analysis was applied to determine the effect of 10 weeks GEL training on teamwork, respect attitude, skill, and physical ability in the experimental group. The basis of decision-making referenced in the Mann-Whitney test: 1) if the value of significance or asymp. sig (2-tailed) $<0.05$ then hypotheses are accepted; 2 ) if the value of significance or asymp.sig (2-tailed) $>0.05$ then the hypothesis is rejected. The following is the descriptive result covering several aspects of teamwork, respect attitude, skill, and physical ability.

\section{Results}

The mean difference in the post-test result between the control and experimental group was based on the significance of the SPSS output $(p<0.05)$. Based on the output in the Mann-Whitney test it is known that the value of team work is $0.039<0.05$; respect attitude of $0.009<0.05$; passing of 0.039 $<0.05$; dribbling of $0.000<0.05$; speed of $0.004<0.05$; power of $0.002<0.05$; endurance of $0.020<0.05$. Therefore, as the basis of the decision-making of the Mann-Whitney test can be concluded that the hypothesis is accepted. So it can be said

Table 3. Descriptive Result of Pre and Post Test on Attitude, Skill, and Physical Ability

\begin{tabular}{clrrrr}
\hline \multirow{2}{*}{ Group } & Attitude, Skill, & \multicolumn{2}{c}{ Pre-Test } & \multicolumn{2}{c}{ Post-Test } \\
\cline { 3 - 6 } & \multicolumn{1}{c}{ Ability } & Mean & SD & Mean & SD \\
\hline \multirow{6}{*}{ Control } & Teamwork & 29.57 & 1.50 & 31.17 & 1.74 \\
& Respect Attitude & 31.43 & 2.01 & 32.74 & 2.09 \\
& Passing & 6.13 & 1.09 & 7.43 & 0.84 \\
& Dribbling & 26.54 & 2.28 & 25.25 & 1.76 \\
& Speed & 5.86 & 0.38 & 5.47 & 0.33 \\
& Power & 29.7 & 4.46 & 32.17 & 4.31 \\
& Endurance & 30.05 & 5.48 & 33.03 & 6.10 \\
\hline \multirow{6}{*}{ Experiments } & Teamwork & 29.87 & 1.42 & 32.35 & 0.99 \\
& Respect Attitude & 32.96 & 1.10 & 34.30 & 1.06 \\
& Passing & 6.43 & 1.16 & 8.21 & 0.73 \\
& Dribbling & 25.18 & 2.02 & 22.80 & 1.15 \\
& Speed & 5.49 & 0.36 & 5.06 & 0.45 \\
& Power & 33.30 & 4.45 & 37.17 & 4.67 \\
& Endurance & 33.33 & 4.35 & 37.45 & 3.97 \\
\hline
\end{tabular}


Table 4. Post-test control and experiment results using Man Whitney test

\begin{tabular}{|c|c|c|c|}
\hline Group & $\begin{array}{c}\text { Attitude, Skill, } \\
\text { and Physical } \\
\text { Ability }\end{array}$ & Mean & Significance \\
\hline $\begin{array}{l}\text { Control } \\
\text { Experiments }\end{array}$ & Team Work & $\begin{array}{l}31.17 \\
32.35 \\
\end{array}$ & 0.039 \\
\hline $\begin{array}{l}\text { Control } \\
\text { Experiments }\end{array}$ & Respect Attitude & $\begin{array}{l}32.74 \\
34.30 \\
\end{array}$ & 0.009 \\
\hline $\begin{array}{l}\text { Control } \\
\text { Experiments } \\
\end{array}$ & Passing & $\begin{array}{l}07.43 \\
08.21 \\
\end{array}$ & 0.039 \\
\hline $\begin{array}{l}\text { Control } \\
\text { Experiments } \\
\end{array}$ & Dribbling & $\begin{array}{l}25.25 \\
22.80 \\
\end{array}$ & 0.000 \\
\hline $\begin{array}{l}\text { Control } \\
\text { Experiments }\end{array}$ & Speed & $\begin{array}{l}05.47 \\
05.06 \\
\end{array}$ & 0.004 \\
\hline $\begin{array}{l}\text { Control } \\
\text { Experiments }\end{array}$ & Power & $\begin{array}{l}32.17 \\
37.17\end{array}$ & 0.002 \\
\hline $\begin{array}{l}\text { Control } \\
\text { Experiments }\end{array}$ & Endurance & $\begin{array}{l}33.03 \\
37.45\end{array}$ & 0.020 \\
\hline
\end{tabular}

that there are significant differences in the value of control groups and experiments. Because there is a significant difference, the formulation of research problems is answered, namely the influence of 10-week Game Experience Learning (GEL) based training on teamwork, respect attitude, skill, and physical ability in young football players (table 3,4 ).

\section{Discussion}

The theory of experiential learning was initiated by Kolb (Lehane, 2020). The experiential learning model is a learning model that emphasizes students' actions to improve knowledge, skills, effectiveness, and creative thinking through hands-on experience (Wilson \& Beard, 2013; Reynolds \& Vince, 2007; Arsoy \& Ozad, 2005). This model was used in the learning of students in the classroom, then the author adopted the theory and developed it into a games experience learning (GEL) applied to young football school students.

Games experience learning (GEL) is a learning and training model that applies the theory of experiential learning, namely learning contains four stages, namely experience in the form of games, reflection, understanding concepts, and implementation. In the games experience learning (GEL) method developed there are two core exercises, both core exercises have the same goal. Phase (1) games, is a tangible form of training media based on Games experience learning (GEL). Games are part of the experience that should be done on every young footballer. Through games, the coach must be precise in deciding the time to do reflection. Phase (2) reflection conveys the moral knowing and moral feeling of a football player. Reflections are done with the direction of the coach, and athletes are given questions by the coach through casual discussions such as questioning «attitudes, what behaviors support success. Why can a player succeed in doing so?». The reflection is very important to develop young footballers during training. (3) the player can find, understand and deduce the concept that the coach expects. The concept of moral behavior of a positive character is expected to be practiced in phase (4) which is the implementation phase.
This study was aimed at investigating the effect of game experience learning (GEL) on teamwork, respect attitude, skill, and physical ability. The findings show that GEL has a significant effect on teamwork and respect attitude. Meanwhile, this technique is a major breakthrough in dealing with the gaps in performance sports development, especially adolescent football players. This is because, studies that examined the physical aspects of the technique were conducted on one specific variable.

The simultaneous combination of several variables is seemingly the right procedure to increase team complexity in football athletes (Eugster, 2012; Liu et al., 2015). This study was in line with previous studies which stated that teamwork is reciprocally working with two or more team members to achieve a goal (Collins \& Durand-Bush, 2019; Gaffney, 2015). Therefore, football provides players, the tendency to change individual play into teamwork. Furthermore, game experience learning is a method that empirically adds to the learning experience hence, improving the characters of players on a team. The results provide a good picture of GEL on teamwork as a means to always work together in achieving desired goals. This was in line with Meiners and Wisdom (2020) which stated that experience-based learning, usually encourage professional skills such as collaboration between one individual and another. However teamwork is not enough to create a good game in football, players are expected to also show respect in the game.

Respectful Attitude is required from every adolescent because it determines how individual respect one another (Utari et al., 2019). Also, it provides an overview for learning through playing experience, where every experience affects the individual's behavior. Therefore, one thing that shapes respectful attitude is the experiencial learning process in a social environment when interacting with one another (Akbar \& Hastjarjo, 2019). Meanwhile, participating in football activities helps young players (12 years) improve communication skills, teamwork, respect for each other, and socialize (Yavuz, 2019). In addition, sports activities not only improve individual physical and mental state but also promote mutual respect (Goksel et al., 2017).

Furthermore, mutual respect in football is an important factor in the development of young players characters (Haugen et al., 2013). In line with this concept, GEL is an important method for developing player characters. Moreover, teamwork and respect is a psychological attribute that must be fostered in improving soccer for young athletes, however, these aspects are not sufficient when the technical and physical abilities are inadequate.

Games experience learning (GEL) based exercises developed by the author is capable of improving skills and physical abilities to achieve peak performance. Besides, skills such as dribbling and passing are fundamental technical components, compulsorily learned from a young age (Doewes et al., 2020). A football player with good dribbling skills is capable of controlling the ball's pace and maneuver through an opponent without losing ball control (Vaidya, 2020). Furthermore, good passing needs to be also considered in football. When players fail to have good passing and dribbling techniques, achieving the desired goals becomes impossible (Vaidya, 2020). The football game also requires good physical abilities. This is one of the most important attribute in achieving maximum performance. An athlete is required to have a qualified physical condition in order to perfectly achieve desired goals (Van Kooten, 2016; McKinney et al., 2019; Dewangga, 2020).

Football is a sports activity in which athletes perform high and low intensity movements (Lilić et al., 2020). Based 
on the observations, coaching young athletes to develop physical aspects especially speed, power, and endurance requires a structured and programmed approach. It also needs to be in line with the long term athlete development theory which state that the main physical aspects that are developed for athletes aged between 12 to 13 years include strength, speed, agility, endurance, power, and special skills in the sports being pursued (Lloyd \& Oliver, 2012). Therefore, experiencebased learning contributes greatly to football coaching, especially in the achievements of complex aspects.

The descriptive results for the control group, pre and post test data, using conventional methods were as follows: teamwork with pre-test mean (29.57), standard deviation (1.50) meanwhile, post-test mean was (31.17), and standard deviation (1.74). For respect attitude, the pretest mean was (31.43), standard deviation (2.01), post-test mean (32.74), and standard deviation (2.09). Furthermore, the pre-test results for passing indicated a mean of (6.13), standard deviation (1.09), post-test mean (7.43), and standard deviation (0.84). Dribbling showed a pre-test mean of (26.54), standard deviation (2.28), post-test (25.25), and standard deviation (1.76). Regarding physical abilities, the pre-test mean for speed was (5.86), standard deviation (0.38), post-test (5.47), standard deviation (0.33). Also, power indicated a pre-test mean of (29.7), standard deviation (4.46), post-test mean (32.17) and standard deviation (4.31). Endurance showed a pre-test mean of (30.05), standard deviation (5.48), post-test mean (33.03) and standard deviation (6.10).

The descriptive results for the pre and post test data of the intervention group using the game experience learning (GEL) based training method were as follows: teamwork with a pre-test mean of (29.87), standard deviation (1.42), posttest (32.35), and standard deviation (0.99). Respect attitude indicated a pre-test of (32.96), standard deviation (1.10), post-test (34.30), and standard deviation (1.06). In addition, passing showed a pre-test mean of (6.43), standard deviation (1.16), post-test mean (8.21), with standard deviation (0.73), while dribbling indicated a pre-test mean of (25.18), standard deviation (2.02), post-test mean (22.80), and standard deviation (1.15). Regarding physical abilities, speed showed a pretest mean of (5.49), standard deviation (0.36), post-test mean (5.06), standard deviation (0.45) while power indicated a pre-test mean of (33.30), standard deviation (4.45), post-test mean (37.17), and standard deviation (4.67). Moreover, for endurance, the pre-test mean was (33.33), standard deviation (4.35), post-test mean (37.45), and standard deviation (3.97). Therefore, based on these results, the intervention group with GEL based treatment training obtained a better average score compared to the control group.

The Mann-Whitney data analysis was conducted to test whether the post-test control and intervention group have a difference in the mean. Based on the SPSS output, there was a significant difference between the two groups in terms of teamwork (0.039), respect attitude (0.009), passing (0.039), dribbling (0.000), speed (0.004), power (0.002), and endurance $(0.020)$. The significance level between both groups were $<0.05$. Therefore, the measured post-test variables for both control and experimental group were not the same. Also, the difference in the mean value for all variables showed that the intervention group has a higher mean value. Thus the effects of 10 weeks of games experience learning (GEL) based exercises for the intervention group had a better improvement compared to the control group.

\section{Conclusion}

Based on the results, the intervention group with games experience learning (GEL) based treatment on teamwork, respect attitude, skill and physical ability have significant differences and show better improvement compared to the control. Therefore, this study provides scientific contribution and reference for further studies.

\section{Conflicting Interests}

The authors declared no potential conflicts of interest.

\section{References}

Schroepf, B., \& Lames, M. (2018). Career patterns in German football youth national teams - A longitudinal study. International Journal of Sports Science \& Coaching, 13(3), 405-414. https://doi.org/10.1177/1747954117729368

Balyi, I., \& Way, R. (2014). Long-term athlete development. In Choice Reviews Online, 51(09). https://doi.org/10.5860/choice.51-5081

Khudolii, O., Ivashchenko, O., Iermakov, S., Veremeenko, V., \& Lopatiev, A. (2019). Motor Abilities: Identification of Development Level in Boys Aged 12-14. Teoriâ ta Metodika Fizičnogo Vihovannâ, 19(3), 139-147. https://doi.org/10.17309/tmfv.2019.3.05

Kavussanu, M., \& Spray, C. M. (2006). Contextual influences on moral functioning of male youth footballers. Sport Psychologist, 20(1), 1-23. https://doi.org/10.1123/tsp.20.1.1

Harwood, C. (2008). Developmental Consulting in a Professional Football Academy: The 5Cs Coaching Efficacy Program. The Sport Psychologist, 22(1), 109-133. https://doi.org/10.1123/tsp.22.1.109 10.1123/tsp.22.1.109

Gilbert, W. D., Gilbert, J. N., \& Trudel, P. (2001). Coaching Strategies for Youth Sports: Part 1: Athlete Behavior and Athlete Performance. Journal of Physical Education, Recreation \& Dance, 72(4), 29-33. https://doi.org/10.1080/07303084.2001.10605736

Henry, I. (2013). Athlete development, athlete rights and athlete welfare: A European Union perspective. International Journal of the History of Sport, 30(4), 356-373. https://doi.org/10.1080/09523367.2013.765721

Hyballa, P., \& te Poel, H. D. (2015). Modernes Passspiel: Der Schlüssel zum High-Speed-Fußball. Meyer \& Meyer Verlag.

Bangsbo, J. (2014). Physiological demands of football. Sports Science Exchange, 27(125), 1-6.

Mohr, M., Krustrup, P., \& Bangsbo, J. (2003). Match performance of high-standard soccer players with special reference to development of fatigue. Journal of Sports Sciences, 21(7), 519-528. https://doi.org/10.1080/0264041031000071182

Rampinini, E., Coutts, A. J., Castagna, C., Sassi, R., \& Impellizzeri, F. M. (2007). Variation in Top Level Soccer Match Performance. Int J Sports Med, 28(12), 1018-1024. https://doi.org/10.1055/s-2007-965158

Bangsbo, J. (2008) Aerobic and Anaerobic training in soccer: with special emphasis on train ing of youth players. Fitness training in soccer I. Bagsvaerd: Ho \& Storm

Bradley, P. S., Sheldon, W., Wooster, B., Olsen, P., Boanas, P., \& Krustrup, P. (2009). High-intensity running in English FA Premier League soccer matches. Journal of Sports Sciences, 27(2), 159-168. https://doi.org/10.1080/02640410802512775

Gonçalves, C. E., e Silva, M. J. C., Cruz, J., Torregrosa, M., \& Cumming, S. (2010). The effect of achievement goals on 
moral attitudes in young athletes. Journal of Sports Science \& Medicine, 9(4), 605.

Khudolii, O., Kapkan, O., Harkusha, S., Marchenko, S., \& Veremeenko, V. (2020). Motor Skills Development: Optimization of Teaching Boys Aged 15 Press Headstand and Handstand. Teoriâ ta Metodika Fizičnogo Vihovannâ, 20(1), 42-48. https://doi.org/10.17309/tmfv.2020.1.06

Malone, M. K., \& Lorimer, R. (2020). The Importance of Shared Understanding within Football Teams. Journal of Sport Psychology in Action, 11(3), 196-210. https://doi.org/10.1080/21520704.2020.1760982

McEwan, D., Ruissen, G. R., Eys, M. A., Zumbo, B. D., \& Beauchamp, M. R. (2017). The effectiveness of teamwork training on teamwork behaviors and team performance: a systematic review and meta-analysis of controlled interventions. PloS one, 12(1), e0169604. https://doi.org/10.1371/journal.pone.0169604

Feigean, M., R'Kiouak, M., Seiler, R., \& Bourbousson, J. (2018). Achieving teamwork in naturalistic sport settings: An exploratory qualitative study of informational resources supporting football players' activity when coordinating with others. Psychology of Sport and Exercise, 38, 154-166. https://doi.org/10.1016/j.psychsport.2018.06.008

Wang, C. (2020). Study on the Evaluation Index of Youth Football Skill Learning. Proceedings of the 2020 International Conference on Management, Economy and Law (ICMEL 2020), 320-323. https://doi.org/10.2991/aebmr.k.201111.054

Rello Pambudi, Y., \& Widiyanto, M. (2019). Football Skills: Training Methods and Motor Educability. 330(Iceri 2018), 322-325. https://doi.org/10.2991/yishpess-cois-18.2018.78

Doewes, R. I., Purnama, S., Syaifullah, R., \& Nuryadin, I. (2020). The effect of small sided games training method on football basic skills of dribbling and passing in indonesian players aged 10-12 years. Int J Adv Sci Technol, 29(3), 429-441.

Romeas, T., Guldner, A., \& Faubert, J. (2016). 3D-Multiple Object Tracking training task improves passing decision-making accuracy in soccer players. Psychology of Sport and Exercise, 22, 1-9. https://doi.org/10.1016/j.psychsport.2015.06.002

Dewangga Yudhistira, T. (2020). Content Validity of Agility Test in Karate Kumite Category. Journal of Human Movement and Sports Sciences, 8(5), 211-216. https://doi.org/10.13189/saj.2020.080508

McKinney, J., Velghe, J., Fee, J., Isserow, S., \& Drezner, J. A. (2019). Defining Athletes and Exercisers. American Journal of Cardiology, 123(3), 532-535. https://doi.org/10.1016/j.amjcard.2018.11.001

Fradua, L., Zubillaga, A., Caro, Ó., Iván Fernández-García, Á., Ruiz-Ruiz, C., \& Tenga, A. (2013). Designing small-sided games for training tactical aspects in soccer: Extrapolating pitch sizes from full-size professional matches. Journal of Sports Sciences, 31(6), 573-581.

https://doi.org/10.1080/02640414.2012.746722

Hill-Haas, S. V., Dawson, B., Impellizzeri, F. M., \& Coutts, A. J. (2011). Physiology of small-sided games training in soccer: A systematic review. Sports Medicine, 41(3), 199220. https://doi.org/10.2165/11539740-000000000-00000

Reilly, T. (2005). An ergonomics model of the soccer training process. Journal of Sports Sciences, 23, 561-572

Ben Khalifa, W., Zouaoui, M., Zghibi, M., \& Azaiez, F. (2021). Effects of Verbal Interactions between Students on Skill Development, Game Performance and Game Involvement in Soccer Learning. Sustainability, 13(1), 160. https://doi.org/10.3390/su13010160

Lehane, L. (2020). Experiential Learning. David A. Kolb. In Science Education in Theory and Practice (pp. 241-257). Springer, Cham.
Wilson, J. P., \& Beard, C. (2013). Experiential learning: A handbook for education, training and coaching. Kogan Page Publishers.

Reynolds, M., \& Vince, R. (Eds.). (2007). Handbook of experiential learning and management education. Oxford University Press.

Arsoy, A. Özad. (2005). The experimental learning cycle in visual design. The Turkish Online Journal of Education Tecnology, 3(2), 1-7.

Eugster, M. J. A. (2012). Performance profiles based on archetypal athletes. International Journal of Performance Analysis in Sport, 12(1), 166-187. https://doi.org/10.1080/24748668.2012.11868592

Liu, H., Yi, Q., Giménez, J. V., Gómez, M. A., \& Lago-Peñas, C. (2015). Performance profiles of football teams in the UEFA champions league considering situational efficiency. International Journal of Performance Analysis in Sport, 15(1), 371-390. https://doi.org/10.1080/24748668.2015.11868799

Collins, J., \& Durand-Bush, N. (2019). The Optimal Team Functioning Model: A Grounded Theory Framework to Guide Teamwork in Curling. Journal of Applied Sport Psychology, 31(4), 405-426. https://doi.org/10.1080/10413200.2018.1512536

Gaffney, P. (2015). The nature and meaning of teamwork. Journal of the Philosophy of Sport, 42(1), 1-22.

Meiners, K. M., \& Wisdom, C. M. (2020). Advancing interpersonal, interprofessional, and clinical skills: Teamwork through training collegiate athletes. Journal of Allied Health, 49(2), E105-E108.

Utari, A. P., \& Sulandari, S. (2019). Respectful Attitude on Adolescents to Elderly.

Akbar, A., \& Hastjarjo, T. D. (2019). Kohesivitas Tim dan Sikap terhadap Kepemimpinan Wasit sebagai Prediktor Kecenderungan Perilaku Agresif Pemain Sepakbola. Gadjah Mada Journal of Psychology (GamaJoP), 4(1), 42. https://doi.org/10.22146/gamajop.45402

Yavuz, C. (2019). The relationships among attitude towards sports, loneliness and happiness in adolescents. Universal Journal of Educational Research, 7(3), 790-796. https://doi.org/10.13189/ujer.2019.070319

Goksel, A. G., CAZ, Ç., Yazici , Ö. F., \& Ikilzer, H. C. (2017). Comparison of Attitudes of Students From Different Departments Towards Sport: the Model of Marmara University. Spor ve Performans Araştırmaları Dergisi, 123123. https://doi.org/10.17155/omuspd.322783

Haugen, T., Säfvenbom, R., \& Ommundsen, Y. (2013). Sport participation and loneliness in adolescents: The mediating role of perceived social competence. Current Psychology, 32(2), 203-216. https://doi.org/10.1007/s12144-013-9174-5

Vaidya, A.S. (2020). Different Techniques And Benefits of Football. Aayushi International Interdisciplinary Research Journal, 7(1), 37-39

Van Kooten, G. C. (2016). Re-Considering Long-Term Athlete Development on Coach Education: An Illustration from Judo. International Sport Coaching Journal, 3(1), 83-89. https://doi.org/10.1123/iscj.2015-0058

Lilić, A., Stanković, N., Joksimović, M., Hadžović, M., Skrypchenko, I., \& Mušović, A. (2020). The importance of corners in the tactical preparation of professional footballers. European Journal of Physical Education and Sport Science, 6(7)

Lloyd, R. S., \& Oliver, J. L. (2012). The youth physical development model: A new approach to long-term athletic development. Strength \& Conditioning Journal, 34(3), 6172. https://doi.org/10.1519/ssc.0b013e31825760ea 


\title{
ВПЛИВ 10-ТИЖНЕВОГО НАВЧАННЯ ІГРОВОГО ДОСВІДУ НА КОМАНДНУ РОБОТУ, ШАНОБЛИВЕ СТАВЛЕННЯ, НАВИЧКИ ТА ФІЗИЧНІ ЗДІБНОСТІ У ЮНИХ ФУТБОЛІСТІВ
}

\author{
Сулістійоно $^{1 \mathrm{ABCDE}}$, Андрі Ахіруянто ${ }^{2 \mathrm{CD}}$, Наван Примасоні ${ }^{3 \mathrm{AD}}$, Фаткурахман Арджуна $^{3 \mathrm{AD}}$, \\ Нурхаді Сантосо $^{3 \mathrm{AD}}$, Деванга Юдхістіра ${ }^{1 \mathrm{BCD}}$
}

\author{
${ }^{1}$ Державний університет Джок'якарти \\ ${ }^{2}$ Державний університет Семаранга \\ зуніверситет Себеласа Маре
}

Авторський вклад: А - дизайн дослідження; В - збір даних; C - статаналіз; D - підготовка рукопису; Е - збір коштів

Реферат. Стаття: 6 с., 4 табл., 46 джерел.

\begin{abstract}
Мета дослідження вивчити ефективність впливу ігрового досвіду, що базується на навчанні, на командну роботу, поважне ставлення, навички та фізичні здібності молодих футболістів.

Матеріали і методи. Учасники складалися з молодих футболістів чоловічої статі, які брали участь у матчах на районному, провінційному та національному рівнях. Кількість залучених учасників склала 46 , розділених на групи контролю та втручання по 23 учасники кожна. Футболісти віком 10-12 років мають зріст 140,98 \pm 7,23 cм, середню масу тіла

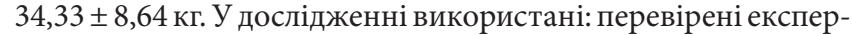
том рубрики спостереження для вимірювання колективної роботи та поваги, тести навичок проходження та дриблінгу, спринту на 30 метрів, стрибків у вертикальному положенні та багатоступеневих тестів для вимірювання фізичних здібностей, швидкості та сили ніг, аеробної витривалості.

Результати. Описові дані показали що середні значення та стандартні відхилення контрольної та втручальної груп, мали відмінності, група втручання мала середні зна-
\end{abstract}

чення та кращі стандартні відхиленння, тоді як тест гіпотези з використанням тесту Манна-Уітні отримав оцінку відношення до командної роботи $0,039<0,05$; ставлення до поваги $0,009<0,05$; прохідні навички $0,039<0,05$; навички дриблінгу 0,000 <0,05; швидкісні здібності 0,004<0,05; сила ніг $0,002<0,05$; витривалість $0,020<0,05$. На основі аналізу даних можна зробити висновок, про достовірну динаміку змінних командної роботи, поважного ставлення, проходження, дриблінгу, швидкості, потужності та витривалості $(\mathrm{p}<0,05)$. Група втручання має більш високі середні значення всіх змінних.

Висновки. Статистичний аналіз виявив суттєвий вплив на командну роботу, поважне ставлення, формування навичок та фізичні здібності молодих футболістів, тому тренування за моделлю навчання ігрового досвіду може бути одним із рішень для покращення результатів юнацького футболу.

Ключові слова: тренування, навчання ігровому досвіду, юний футболіст.

\section{Information about the authors:}

Sulistiyono: sulistiyono@uny.ac.id; https://orcid.org/0000-0002-6304-1403; Departement of Sports Science, Faculty of Sport Science, Yogyakarta State University, Jl. Colombo Yogyakarta No.1, Karang Malang, Caturtunggal, Kec. Depok, Kabupaten Sleman, Daerah Istimewa Yogyakarta 55281, Indonesia.

Akhiruyanto Andry: andryakhiruyanto@mail.unnes.ac.id; https://orcid.org/0000-0001-9567-7046; Department of Physical Education, Health and Recreation, Faculty of Sports Science, Universitas Negeri Semarang, Sekaran, Gunung Pati, Semarang City, Central Java 50229, Indonesia.

Primasoni Nawan: nawan_primasoni@uny.ac.id; https://orcid.org/0000-00002-9560-0089; Departement of Sports Science, Faculty of Sports, Sebelas Maret University, Jl. Ir. Sutami No.36, Kentingan, Kec. Jebres, Kota Surakarta, Jawa Tengah 57126, Indonesia.

Arjuna Fatkurahman: arjuna@uny.ac.id; https://orcid.org/0000-0001-6920-9281; Departement of Sports Science,, Faculty of Sports, Sebelas Maret University, Jl. Ir. Sutami No.36, Kentingan, Kec. Jebres, Kota Surakarta, Jawa Tengah 57126, Indonesia. Santoso Nurhadi: nurhadi_santoso@uny.ac.id; https://orcid.org/0000-0001-9123-2859; Departement of Sports Science, Sebelas Maret University, Jl. Ir. Sutami No.36, Kentingan, Kec. Jebres, Kota Surakarta, Jawa Tengah 57126, Indonesia.

Yudhistira Dewangga: dewangga0021fik.2020@student.uny.ac.id; https://orcid.org/0000-0002-4194-1283; Departement of Sports Science, Faculty of Sport Science, Yogyakarta State University, Jl. Colombo Yogyakarta No.1, Karang Malang, Caturtunggal, Kec. Depok, Kabupaten Sleman, Daerah Istimewa Yogyakarta 55281, Indonesia.

Cite this article as: Sulistiyono, Akhiruyanto, A., Primasoni, N., Arjuna, F., Santoso, N., \& Yudhistira, D. (2021). Effect of 10 Weeks Game Experience Learning (Gel) Based Training on Teamwork, Respect Attitude, Skill and Physical Ability in Young Football Players. Teoriâ ta Metodika Fizičnogo Vihovannâ, 21(2), 173-179. https://doi.org/10.17309/tmfv.2021.2.11

Received: 16.04.2021. Accepted: 14.06.2021. Published: 25.06.2021

This work is licensed under a Creative Commons Attribution 4.0 International License (http://creativecommons.org/licenses/by/4.0). 